'Breeding for Success: Diversity in Action' C.F. Mercer (ed).

Proceedings of the $13^{\text {th }}$ Australasian Plant Breeding Conference,

Christchurch, New Zealand 18-21 April 2006. pp. 408-412.

\title{
Breeding for improved frost-seeded red clover seedling establishment
}

\section{Heathcliffe Riday}

US Dairy Forage Research Center, USDA-ARS, 1925 Linden Drive West, Madison, WI 53706, USA

Abstract. In the colder parts of the United States, in late winter after disappearance of snow cover, red clover (Trifolium pratense) is often broadcast seeded into forage legume-depleted grass pastures to increase pasture forage quality. This method of establishment is referred to as frost seeding. However, in an estimated $30-40 \%$ of frostseeded pastures in Wisconsin, USA the legumes fail to establish. In this study 40 red clover halfsib families from one breeding population and six check populations were evaluated for spring 2005 establishment by 1 ) broadcast seeding into existing pasture under frost-seeded conditions and 2) standard drill seeding into $15 \mathrm{~cm}$-spaced rows. In June 2005 seedling counts and heights were measured on halfsib family plots. Narrow sense heritability estimates on a halfsib family basis for seedling stand counts under frost- and drill-seeded establishment were $h^{2}=0.02$ and 0.21 respectively. Heritabilities for seedling height under frost- and drill-seeded establishment were $h^{2}=0.50$ and 0.26. Genetic correlations between seedling counts and heights under frost- and drill-seeded establishment were $r_{\mathrm{A}}=0.42$ and 0.19 respectively. No significant genetic correlations between frost- and drill-seeded heights $\left(r_{\mathrm{A}}=-0.09\right)$ or seedling counts $\left(r_{\mathrm{A}}=0.20\right)$ were detected. These results suggest that seedling performance in frost-seeded conditions is a distinct trait from seedling performance in standard drill-seeded conditions and that each needs a separate selection program.

\section{Introduction}

Red clover (Trifolium pratense) is grown in the more humid regions of the USA under various management schemes (Taylor and Smith, 1995). One major use of red clover is in pasture systems. It is estimated that in 1987 there were 4.5 million acres of red clover/grass mixtures in the United States (Taylor and Smith, 1995), representing close to $20 \%$ of all forage acreage in the United States (USDA-NASS, 2005). Red clover/grass mixture acreage has likely increased since 1987 (Smith, 2000). In Wisconsin, USA a survey of grazed pastures showed $46 \%$ contained red clover, which was second only to white clover in abundance at 60\% (Brink and Casler, 2004).

One advantage of red clover is its shade tolerance, allowing the plant to accumulate more biomass under low light conditions than other small-seeded forage legumes (Gist and Mott, 1957). Red clover has a light compensation point at $6 \%$ of daylight (Taylor and Smith, 1995). This advantage makes red clover the best smallseeded forage legume to overseed onto existing grass pastures (Undersander, et al., 2002; Morrison, 2003; Shaeffer et al., 2003). A disadvantage of red clover is its lack of persistence; however, improved persistence has been achieved through breeding efforts spanning the past half century. Under a three-cut management scheme with and without grass, modern red clover germplasm has been shown to persist productively into the fourth year of a stand (Smith, 2000).

Red clover's excellent seedling vigor coupled with its lower persistence has led to the common practice, in many parts of the USA, of yearly frost seeding of red clover into grass pastures. Frost seeding involves broadcast seeding onto existing pasture, and, for red clover, usually takes place 1-2 months before the regular small-seeded forage 
legume planting date, just after the snow has melted and the ground is still subject to freeze/thaw action of temperature changes. Establishment failure rates for frost seeding have been estimated to be between 30-40\% (Undersander, 2003).

This study had three objectives: 1) to measure the genetic variation and heritability of frost-seeding red clover for possible future breeding and variety development; 2) to test an experimental protocol for small plot red clover frost seeding into existing grass sod with limited amounts of available seed; and 3) to compare red clover frost-seeded establishment to regular drill-seeded establishment.

\section{Materials and methods}

Seed of 40 halfsib families from an elite experimental US Dairy Forage Research Center (USDFRC) red clover population 'C584' were used. Seed of six other populations were used as well: 'Arlington' and 'Marathon' (USDFRC varieties); 'C328' and 'HC82/83' (USDFRC experimentals); 'Duration' (Allied Seed); and 'AC Christie' (Agriculture and Agri-Food Canada). These 46 entries were frost- and drillseed established. An additional four varieties were only frost-seeded: 'Cherokee' (University of Florida), Cinnamon Plus (Allied Seed), 'Redland Graze II' and 'Concord' or 'Redland III' (ABI Alfalfa, now Forage Genetics - Land O’Lakes). $\underline{\text { Site A }}$

Fifty entries were frost-seeded at the USDA-ARS, US Dairy Forage Research Dairy in Prairie du Sac, Wisconsin, USA ( $\left.43^{\circ} 19^{\prime} \mathrm{N}, 89^{\circ} 44^{\prime} \mathrm{W}\right)$. Plots were seeded into continuously grazed, naturalized Kentucky bluegrass (Poa pratensis L.) permanent pasture [soil type: Richwood silt loam (fine-silty, mixed, superactive, mesic typic argiudolls)]. The pasture area was continuously grazed during 2004 to a $1-2 \mathrm{~cm}$ stubble height. The pasture was sprayed with herbicides to eliminate non-grass species in late Autumn 2004. Snow melt at the pasture site occurred during the end of March in 2005. Plots were hand-broadcast seeded using a $60 \mathrm{~cm}$ x $60 \mathrm{~cm}$ wooden box on 1 April, 2005 . Plots were separated from other plots by $60 \mathrm{~cm}$ non-red clover borders. The broadcast seed material consisted of 300 seeds per plot (12.5 kg PLS/ha) mixed with sand to facilitate even seed distribution. The 50 entries were arranged in an $\alpha$-lattice with three replicates and five incomplete blocks per replicate, with each incomplete block containing 10 plots. Plots were not grazed until the end of July 2005.

$\underline{\text { Site B }}$

Forty-six entries were drill seeded at site A and at the Arlington Agricultural Research Station, Wisconsin, USA (site B) $\left(43^{\circ} 18^{\prime} \mathrm{N}, 89^{\circ} 21^{\prime} \mathrm{W}\right)$ [soil type: Plano silt loam (finesilty, mixed, superactive, mesic typic argiudolls)]. Plots were seeded with one row per family, into a firm seedbed at $1 \mathrm{~cm}$ depth, in $75 \mathrm{~cm}$ long rows, with 75 seeds per row (10 kg PLS/ha) using a single row V-belt planter. Rows were separated by $15 \mathrm{~cm}$. Plots were planted 15 and 18 April, 2005 at site A and site B respectively.

The design at each drill seeded location was a lattice with two replicates and 16 incomplete blocks per replicate, with each incomplete block containing 16 plots. Only 46 of 256 entries were reported (entries reported were those entered into the frostseeded study). Data for the 46 entries of interest were adjusted for incomplete blocks. Replicates across both locations were combined into four replicates for the drill-seeded treatments.

Height and seedling counts were taken on 29 June, 2005 in the frost-seeded plots and on 21 and 23 June, 2005 for the drill-seeded plots. In the frost-seeded plots, two counts were taken of all plants in two diagonally adjacent $30 \mathrm{~cm}$ x $30 \mathrm{~cm}$ squares within 
the $60 \mathrm{~cm}$ x $60 \mathrm{~cm}$ plots. Within one of the count areas, heights were measured on five randomly selected plants. In the drill-seeded plots the total number of plants per plot was counted, in addition to height for five randomly selected plants.

An average height and plant count for each plot in both planting treatments was then calculated. Means and genetic variance components were estimated using PROC MIXED in SAS. Standard errors around the additive genetic variance components were calculated directly using the COVTEST option of the PROC MIXED procedure in SAS (SAS, 1999). The standard error estimates were very similar to estimates using approximate variance of variances estimates described by Hallauer and Miranda (1988). Heritabilities were estimated based on variance component estimates and heritability estimate $90 \%$ confidence intervals were estimated following Knapp et al. (1985).

\section{Results}

Red clover stands were successfully established by frost seeding onto permanent pasture and drill seeding into prepared seedbeds (red clover stands are adequate at $>110$ plants $/ \mathrm{m}^{2}$ ). In drill-seeded plots $28 \%$ of seed developed into seedlings, while in the frost-seeded plots only $15 \%$ of seeds developed into seedlings (seed germination in laboratory was 95\%). No significant differences for height were observed in frost- vs. drill-seeded treatment means.

Among varieties in the frost-seeded establishment, 'Cinnamon Plus' and 'Duration' had the highest seedling establishment and height (Table 1) but were only significantly better than 'AC Christie'. Likewise, in the drill- seeded plots, 'C328' and 'HC 82/83' had the highest seedling counts but were only significantly better than 'AC Christie', and there were no significant differences for seedling height. For both establishment methods 'C584' was in the low mid-range for seedling counts and height. Narrow sense heritability estimates were greater for seedling height measurements than seedling counts in both frost- and drill-seeded plots (Table 2). Heritability for seedling counts in frost-seeded plots was negligible. Genetic correlations between seedling height and counts in frost- and drill-seeded plots were $r_{\mathrm{A}}=0.42$ and 0.19 . Correlations between establishment treatments for seedling height and count were low $\left(r_{\mathrm{A}}=0.20\right.$ and $\left.r_{\mathrm{A}}=-0.09\right)$. 
Table 1. Means of ten varieties and 'C584' half sibs, C584 $\sigma_{A}^{2}$ for seedling height $(\mathrm{cm})$ and counts (seedlings $/ \mathrm{m}^{2}$ ) for frost-seeded (onto pasture) and drill-seeded (into seedbed) establishment methods for plots established in April, 2005 in Wisconsin, USA.

\begin{tabular}{lcccc}
\hline \multirow{2}{*}{ Variety } & \multicolumn{4}{c}{ Establishment } \\
& Frost-seeded (site A) & \multicolumn{2}{c}{ Drill-seeded (site A and B) } \\
& Height & Count & Height & Count \\
\hline & $\mathrm{cm}$ & seedlings/ $\mathrm{m}^{2}$ & $\mathrm{~cm}$ & seedlings/ $\mathrm{m}^{2}$ \\
AC Christie & 7.7 & 99 & 14.5 & 81 \\
Arlington & 10.5 & 151 & 14.8 & 164 \\
C328 & 10.6 & 131 & 16.9 & 219 \\
Duration & 14.6 & 152 & 15.5 & 134 \\
HC82/83 & 8.2 & 116 & 15.1 & 213 \\
Marathon & 13.9 & 134 & 16.6 & 173 \\
Cherokee & 12.6 & 138 & - & - \\
Cinnamon Plus & 15.0 & 158 & - & - \\
Concorde & 9.7 & 136 & - & - \\
Redland Graze II & 12.6 & 117 & - & $\mathbf{1 8 7}$ \\
C584 & $\mathbf{1 0 . 9}$ & $\mathbf{1 3 4}$ & $\mathbf{1 4 . 7}$ & 71 \\
\hline LSD $(\mathrm{P}=0.05)$ & 5.5 & 36 & 2.6 & $71 \pm 21$ \\
C584 $\sigma_{\text {A }}^{2} \pm$ SE & $4.91 \pm 0.59$ & $12 \pm 12$ & $0.28 \pm 0.25$ & \\
\hline
\end{tabular}

Table 2. Narrow sense heritability estimates $\left(h^{2}\right)$ of population 'C584' for seedling counts and height for frost-seeded (onto pasture) and drill-seeded (into seedbed) establishment methods, with $90 \%$ confidence intervals (in brackets) for plots established in April, 2005 in Wisconsin, USA.

\begin{tabular}{ccccc}
\hline \multicolumn{4}{c}{ Frost-seeded } & \multicolumn{2}{c}{ Establishment Method } & \multicolumn{2}{c}{ Drill-seeded } \\
& Height & Count & Height & Count \\
\hline${ }^{\prime} \mathrm{C} 5844^{\prime} h^{2}$ & $0.50(0.19,0.51)$ & $0.02(-0.59,0.37)$ & $0.26(-0.18,0.51)$ & $0.21(-0.26,0.47)$ \\
\hline
\end{tabular}

\section{Discussion}

Although frost-seeded seedling count differences were noted between varieties, it was disappointing to see negligible heritability values. Seedling heights did have higher heritability values than seedling counts. However, successful stand establishment ultimately depends on high seedling establishment rates. Indirect selection for increased frost-seeded seedling counts using seedling height is possible; however, the genetic correlation is quite low, suggesting that it would be difficult to effectively select for seedling establishment counts in 'C584'. Selection out of other tested populations might facilitate improvement, since some of these were superior to the mean of ' $\mathrm{C} 584$ '.

The lack of genetic correlation between frost- and drill-seeded plots suggests that seedling performance under different establishment methods are traits under separate genetic control and need distinct selection programs. However, environmental 
factors do play a large role in establishment rates. Spring 2005 was very dry at the establishment locations. In the frost-seeded study, soil moisture patchiness was observed as the grass utilized available moisture. The lattice design was able to compensate for some of this variation; however, the 2005 drought provided a stark demonstration of the great impact environment has on seedling establishment. Additional test years are necessary to determine if environment or establishment management is the reason for the lack of correlation between establishment methods.

Supporting the hypothesis that frost-seeded and drill-seeded establishment are traits under separate genetic control, Allied Seed varieties 'Duration' and 'Cinnamon Plus' showed superior performance under frost-seeding, while USDFRC populations 'C328' and 'HC82/83' excelled under drill-seeded conditions. Breeding entities often have distinct genetic pools from which populations are developed; therefore, observing that each entity's germplasm excelled under one of the two different establishment methods would suggest these traits are under distinct genetic controls.

\section{References}

Brink GE, Casler MD (2004) The Grass Works Pasture Survey. Proceedings of Wisconsin Grazing Conference. http://www.ars.usda.gov/research/publications/ Publications.htm?seq no $115=161481$

Gist RG, Mott GO (1957) Some effects of light intensity, temperature, and soil moisture on the growth of alfalfa, red clover and birdsfoot trefoil seedlings. Agronomy Journal. 49:33-36.

Hallauer AR, Miranda JB (1988) Quantitative genetics in maize breeding. Iowa State University, Ames, IA.

Knapp SJ, Stroup WW, Ross WM (1985) Exact confidence intervals for heritability on a progeny mean basis. Crop Science 25:192-194.

Morrison JA (2003) Hay and pasture management. In. 'Illinois Agronomy Handbook (23 ed.)' (Eds R. Hoeft and E. Nafziger) chapter 8.

SAS. 1999. SAS Institute Inc., Cary, NC.

Sheaffer CC, Ehlke NJ, Albrecht KA, Peterson PR (2003) In 'Forage Legumes ( $2^{\text {nd }}$ ed.)' Minnesota Agricultural Experiment Station bulletin 608-2003.

Smith RR (2000) Red Clover in the "twenty-first" century. In "Proceedings of the $24^{\text {th }}$ Forage production and use symposium'. Wisconsin forage council. http://www.uwex.edu/ces/forage/wfc/proceedings2000/smith.htm .

Taylor NL, Smith RR (1995) Red Clover. In 'An introduction to Grassland Agriculture Forages Vol.1. (5thed.)' (Eds RF Barnes, DA Miller, CJ Nelson) Iowa State University, Ames, IA. pp 217-226.

Undersander DB, Albert D, Cosgrove D, Johnson P, Peterson PR (2002) In 'Pasture for profit: a guide to rotational grazing' University of Wisconsin and University of Minnesota Extension Service publication A3529.

Undersander D (2003) Frost seeding forages. University of Wisconsin Extension http://www.uwex.edu/ces/forage/pubs/frostsd.htm

USDA National Agricultural Statistical Service (2005) Agricultural Statistics 2005. United States Government Printing Office, Washington D.C. 